\title{
8 Nordic populists as hegemony challengers
}

\author{
Emilia Palonen and Liv Sunnercrantz
}

This chapter explores populism in Nordic countries where there is a long tradition of heterogeneous, populist parties with incompatible political ideologies transforming over decades. Between the anti-communism, anti-elitism, antitax-paying, anti-immigration, and agrarian features, little unites these parties. We argue, however, that at least one feature fits: they were all hegemony challengers. This may indeed be a feature of populism as such following the theory of Ernesto Laclau. ${ }^{1}$ Hence, a particular study of Nordic populists would reveal hegemony as the particular shared social imaginary horizon in each of the Nordic countries. The chapter develops a Laclaudian understanding of populism and provides a chronological narrative of the populist parties in Finland, Denmark, Norway, and Sweden, and a discussion of hegemony as it emerges and transforms over time. Populist parties have emerged as a reaction to dominant thinking in each of the political contexts. Our study explores alternatives or points of contestation regarding key issues emerging during the studied period, most notably relations to the Soviet Union and market deregulation as well as migration and welfare chauvinism.

There are several ways to approach populism, and Nordic populist parties have been studied from ideational perspectives as well as a party family. ${ }^{2}$ Our post-Gramscian approach to populism includes an idea of hegemony and counter-hegemony: populist parties are challengers of the status quo who seek to offer a new alternative vision, question, or basis of argumentation for a political 'us'. ${ }^{3}$ Two features mark Nordic politics: the strong position of Social Democratic parties and a culture of consensus in coalition governments, as stressed by David Arter. ${ }^{4}$ Despite the potential for conflict, overriding social democratic ideals enabled a political culture where issues were settled through compromise. Low levels of conflict over the basic rules of the political process and the exercise of power combined with a high degree of concertation in public-policy creation characterise this culture of consensus. ${ }^{5}$ While we do not study consensus politics per se, we do investigate how hegemony challengers have fertilised and used the powerful myth of a social democratic consensus (although in Finland this position has been occupied by the Centre Party). ${ }^{6}$ The emergence of populist parties has to be analysed with view to this initial setup. The most prominent feature that we find when exploring Nordic populist 
parties is that they challenge a status quo that transforms over time. Studying populist parties in the Nordic countries not only reveals - often unsuccessful alternatives these parties pursued in politics, but what they sought to challenge. Until now, the research on populist parties has focused on their ideology or style, or on voters, in line with dominant trends such as the ideational approach in political science. ${ }^{7}$ While we recognise similar topoi as ideological contents like some previous researchers, ${ }^{8}$ our contribution lies in the logic of populism. The logic is not reducible to a tool kit, although it might benefit from it or the hybrid media system. ${ }^{9}$ Furthermore, adding to research on the radical right, we insist that anti-immigration is not synonymous with populism, although it may entangle it. ${ }^{10}$

From our perspective, populism is not an ideology or substance. It is debatable whether it is ideological at all. ${ }^{11}$ Political theorists Ernesto Laclau and Chantal Mouffe conceptualise populism as a logic of articulation. Accordingly, the substance of populism is a particular logic or form. ${ }^{12}$ It is composed of three ingredients - an abstract content of identification: 'us'; a dichotomy with 'them'; and an element that grips the audience - through passion or an emotional attachment. We have simplified this into the following formula: Populism $=u s^{\text {affect } 1}+$ frontier ${ }^{\text {affect } 2}$. Rather than looking for particular ideas tied to populism, the formula allows us to analyse populism as a performative process. In a given rhetorical situation, the 'us' category of identification can be substituted with various forms of universal and inclusive forms of 'us' that can take up the representation of the political subject that integrates disparate identities and demands into temporary unity. Who gets defined as 'them' or what lies beyond the 'frontier' also constitutes 'us'. As hegemony is constituted through otherness, in this study we demonstrate that it is not constant. Over time and through different political actors and movements, the contents of 'us' and the 'frontier', alongside the affects and emotions that heighten them, transform. ${ }^{13}$

Theoretically, generating a typology between populist parties, we divide populist parties into mainstream and fringe populist parties. Mainstream populists seek to take over political space as a whole from a central position in the core of politics, as one of the larger and often traditional parties. Fringe populist parties and movements would challenge all the other parties from a supposed outside. They seek a position outside the core: they operationalise the 'frontier' against the other established parties. It is typically fringe populist parties we discuss in this case of Nordic countries. If they attempt to advance their positions, fringe-leaning parties face challenges such as how to claim a mainstream position and successfully represent the whole political field. To further develop the understanding of populism, we argue that populism is not constant but emerges in moments. Here, we analyse particular 'populist' movements and political parties and recognise the form of populism in their rhetoric and articulations. ${ }^{14}$ The study of Nordic populism stresses the particularity of Nordic countries as a particular region in Europe with its historical contingencies.

The Nordic countries differ from the Latin American countries Laclau studied. There, the populist party were the parties of the people rather than the 
elites, and workers rather than industries dominated the spectrum. Yet their power became institutionalised while the political spectrum polarised. They became mainstream populist parties. Laclau sought to theorise on a more universal level taking examples from the Russian Revolution and the workers' movements: populism has to do with mobilisation and becoming, temporarily, the people. ${ }^{15}$

Our analysis shows that the emergence of Nordic populist parties has, in particular, to do with a reaction against the hegemony, which could also manifest itself as overall shared imaginary rather than particular policy positions. Hegemonic discourses or imaginaries with overarching concepts in the Nordic countries could, of course, be seen from different angles, just as Götz and Markund with their colleagues have demonstrated studying Nordic 'openness'. ${ }^{16}$ Consensus may also refer to the lack of diversity of opinions; contesting it would mean calling for plurality over polarisation or single-vision. ${ }^{17}$ From the discourse-theoretical perspective hegemony is something that becomes consensual, unquestioned and sedimented through political practice. It is distinct from a set of practices of power sharing and policy-making - although these may play a part in the process of hegemonisation. Furthermore, we analyse how populist parties have contested sedimented and institutionalised practices (including consensual decision-making) in the Nordic countries.

In her work from the 1990s and the 2000s, Chantal Mouffe, Laclau's partner and co-theorist, drew on experiences from her native Belgium and another country she frequents, Austria. In Austria, the emergence of the Freedom Party (FPÖ) with their leader Jörg Haider was a reaction from the regions against the consensus of the Viennese elites; rather than a racist vote as it had been interpreted by those elites, she explained. ${ }^{18}$ Similar regionalism can be found in our Nordic set. We see it in the Finnish Rural Party (Suomen maaseudun puolue, SMP) - as the name would indicate, ${ }^{19}$ and in the Danish national election of 2015, when the Danish People's Party's (Danske Folkeparti) success in rural areas can be attributed partly to their representation of the rural region against the capital. ${ }^{20}$ Likewise, the emergence of the Finns Party (Perussuomalaiset) and the Sweden Democrats (Sverigedemokraterna) has been reduced to racism and anti-immigration of the left-behinds of global capitalism, rather than an anti-elitist and anti-consensus response. Although, as Ainur Elmgren has highlighted in her chapter, the anti-consensus Finns Party has indeed called for openness challenging the Finnish elites on their own ground, just as they perform consensus as closure. ${ }^{21}$ Digging deeper into the background of populists in Finland and Sweden, we see that racism and anti-elitism intertwine, but there are also other features to challenge and contest. In neighbouring Norway and Denmark, populist parties have focused first and foremost on issues of taxation. While nation-centrism and a focus on the people were present in those parties, it was only in the late 1980 s that they adopted an anti-immigration discourse. $^{22}$

Consensus culture in politics is present in all Nordic countries but political systems differ. In countries like Sweden, left-right coalition ('bloc') voting has 
divided the political spectrum and often results in minority governments. ${ }^{23}$ Forming a government had been rather simple until 2014, as Kjell Östberg discusses in his chapter. By contrast, in Finland, elections give voice to individual candidates on party lists, and can cause bottom-up ordering of policy-makers. Yet, there had traditionally - until the elections in 2015 - been three major parties, two of whom had invariably been in a majority coalition government: the former agrarian Centre Party (Centre), the Social Democratic Party (SDP) and the right-wing bourgeois National Coalition Party (NC). Until 2015, this praxis had generated some continuity in politics. For example, none of the governments have sought to radically alter the Finnish welfare state, and this continuity has been praised as a key feature of Finnish democracy. In both Finland and Sweden, the strong status of trade unions and the praxis of negotiation between the employers' and workers' representatives has further sedimented consensus. It has been difficult for a single political party to challenge the power of three large parties and corporatism ${ }^{24}$ and demonstrate whether these are society-wide phenomena, as the SMP and Green Party examples show. ${ }^{25}$

Nordic populist parties have experienced waves of popularity related to different grievances and protests: from elitism in the 1960s to taxes in the 1970s-1980s and to immigration from the 1980s and onward. A common thread through these cases is the welfare state as a point of contestation. ${ }^{26}$ The exact rise, decline and forms of expression of populist challengers in the Nordic countries vary within the social context. While populist parties emerged in Denmark, Norway, and Finland in the late 1970s; Sweden only caught up with this trend many years later. ${ }^{27}$ Researchers have questioned why it took such a long time for a markedly populist party to gain ground in Sweden, in comparison to neighbouring countries. ${ }^{28}$ We explain how, in the early 1990 s, Swedish New Democracy (Ny Demokrati) utilised the populist appeal of the broader neoliberal movement, which lacked direct parliamentary representation at the time. ${ }^{29}$ In this study, we particularly look at the hegemony challengers' emergence in Sweden.

\section{0s-1960s and onwards: emergence of the Finnish rural party}

The Finns Party's predecessor Finnish Rural Party (SMP) emerged as an antiSoviet, anti-bourgeoisie, anti-elitist front as a response to both the Agrarian Party's affluent small-holder tradition, and the socialism of both anti-Soviet and pro-Soviet left. Founder Veikko Vennamo was elected to the Finnish Parliament Eduskunta in the 1940s and 1950s representing the predecessor of the Agrarian Party (Maalaisliitto) today's Centre Party. He deviated from the mainstream of the party backing Urho Kekkonen, and ultimately joined a new party of the small-holders that was formed into the SMP. The new party gained from Vennamo's networks as he was leader of the office administering the post-war settlement to the current borders of Finland, Eastern Karelia. They established themselves mostly in rural communities and suburbs, but were set apart from 
the locals due to their dialect, and rural communities were not always inclusive. Vennamo drew support from the party from his formal employment where he took care of settling the Finnish refugee population after the war. Attention to the marginalised and excluded, and the anti-elitist rhetoric defending the 'ordinary people' was characteristic to the Finnish Rural Party, with Vennamo as the key orator.

Among the Finnish parties, the SMP sought to provide an alternative to the Agrarian Party led by Urho Kekkonen, who eventually became the longest serving president of Finland and was a keen negotiator with the Soviets from the 1950s. The anti-Soviet stance was a useful tool for Vennamo. ${ }^{30}$ It would resonate among the settlers, contest the hegemony of Kekkonen's Agrarian Party, and challenge so-called Finlandisation, which was becoming a norm. Much of the polarisation was personified between Vennamo and Kekkonen. In the historical landslide elections of 1970, SMP went from 1 to 10 per cent of the vote and demanded a non-communist government. The Agrarians went back and forth in negotiations with Vennamo: some in the Agrarian Party thought that if SMP stayed in opposition they would become too strong. The Communists (SKP) protested the possibility of SMP in the government, which fuelled Kekkonen's worries that SMP could play the card of old parties being against them. ${ }^{31}$

Leading contemporary analysts, such as Risto Sänkiaho, locate the SMP between the Left and Right and discuss urbanisation and the use of recognisable and strong rhetoric. ${ }^{32}$ As Aarni Virtanen demonstrates in his thorough study, Vennamo and his movement were branded systematically as fascist in Kansan Uutiset, the newspaper of the party of the left SKDL and communist SKP. Kekkonen also supported this view, and this kind of branded cordon sanitaire made it difficult for the political right to collaborate and associate with them. Virtanen's analysis brings to the fore the combination of clear non-socialism, anticommunism, and the left-wing policies and right-wing conservative values in Vennamo's SMP. The party sought to represent the rural poor (the lumpenproletariat, one could say). Moving to the suburbs and the increasing fluidity of party identification enabled support for a relatively new party. ${ }^{33}$ Around the 1970 elections, the SKP informed East German comrades about the fascist SMP and the reactionary National Coalition Party (Kokoomus). Non-socialist coalition building, however, always failed. The party put their faith in SDP's Mauno Koivisto and got a victory from their arch opponent Kekkonen when Koivisto (once the favourite of Kekkonen) was chosen as his successor. ${ }^{34}$

In terms of socio-economic groups, the SMP's main competition was from the further left-wing parties, and here anti-communism set them apart. It also challenged the Agrarian Party, which could be seen as too liberal or representing the more well-off people. In 1970 Kokoomus leaned to the left in their social policy. Both Kokoomus and SMP were eager to get into government. This meant collaborating with the Agrarian-Centre Party. For both of them, challenging the status quo did not target the welfare state, but objected to the power of the KGB and Soviet influence in Finnish internal affairs. While under 
Holkeri's leadership, Kokoomus was moving towards collaborating with Kekkonen's Centre, and when he saw a change, Vennamo began to collaborate. On many occasions in the 1960s and the 1970s, parliamentarism was more visible in contrast to Kekkonen's presidentialism (in a semi-presidential system): SMP was an extremely active party in the parliament, and what Vennamo and his colleagues were getting in trouble for was speaking too much in parliament. So the label of populist anti-parliamentarism does not hold here. Koivisto finally launched the long legislative process of increasing the power of the parliament over the president.

Although this negative branding about the emergence of a fascist movement existed, it is difficult to argue that the roots of the Finns Party would have been outright nationalist-xenophobic, ${ }^{35}$ in part because immigration was not a salient issue or policy field. ${ }^{36}$ None of the other Nordic countries witnessed anti-immigration right-wing populism from the start.

\section{0s: emergence of right-wing tax populism in Denmark and Norway}

Right-wing populist parties emerged in both Denmark and Norway in the 1970s. Their points of contestation were bureaucracy and tax burdens, which they framed as unjust and out of proportion. These parties' discourses were initially not concentrated around the national people, nor did they mobilise an active opposition against immigration until the 1980s.

Lawyer Mogens Glistrup became known to the Danish public when he, on live television in 1971, revealed that he, lawfully, circumvented all income tax thus exposing the shortcomings of the existing system. A year later, he founded the Danish Progress Party (Fremskridtspartiet) in the fight against income taxes, bureaucracy, and the extent of the public sector. The Progress Party burst into parliament as the second-largest party in the 'landslide election' of 1973 and remained in parliament until 1999. Although Glistrup's rhetoric was somewhat xenophobic from the outset, the anti-immigrant message became more prominent in the 1980s. ${ }^{37}$

The precursor to the Norwegian Progress Party is usually traced to the establishment of Anders Lange's Party for a Strong Reduction in Taxes, Duties and Public Intervention (Anders Langes Parti til sterk nedsettelse av skatter, avgifter og offentlige inngrep; ALP) in 1973. Lange, inspired by Glistrup, opposed bureaucracy, state capitalism, and socialism. He was a strong supporter of neoliberalism. When Carl I. Hagen took leadership in 1978, the ALP became the Progress Party (Fremskrittspartiet) and quickly gained swing-vote leverage. ${ }^{38}$

Nordic countries experienced similar discussions even though populists were not everywhere in the forefront of liberalising economy. Meanwhile, in Finland, the Korpilahti meeting brought 'consensus': it mainstreamed the idea of shrinking the role of state companies, sustained criticism of the welfare state and highlighted the need to improve competitiveness. Meeting up in a hotel in a remote part of Espoo, a city neighbouring Helsinki, was enough to 
mainstream several ideas among the political elites. The move from the welfare state system towards the right happened within the existing political parties and their mutual balance ${ }^{39}$ rather than through a new or anti-welfare statist populist actor.

\section{0s: towards xenophobia from mainstreaming neoliberalism}

During the 1980s, the Danish Progress Party was torn by internal factions. Glistrup served time for tax evasion and upon his release in 1985 railed against Muslims as a threat to Danish identity. In the meantime, the party experienced their worst election results ever in 1984 under Pia Kjærsgaard, who officially became party leader in the mid-1980s. While the Danish Progress Party had started out as a populist-libertarian project, they took a more xenophobic turn around this point. ${ }^{40}$ Simultaneously, radical right-wing protest groups and racist subcultures gained ground in Denmark during the 1980s (inspired by radical right-wing projects in Germany and France). The Left suffered from visionary disorientation and demobilisation as the Eastern Bloc started to collapse. Radical right-wing rhetoric gained disproportionate media attention. The Progress party used the momentary attention on the EU and immigration as well as the consensus among mainstream parties (who nevertheless failed to hegemonise the public discourse) to take up a contesting, alternative position. ${ }^{41}$

Swedish business interpreted the employee funds in 1983 as a breach from the old consensus between labour and capital. ${ }^{42}$ Business, think tanks, and intellectuals joined forces as Swedish neoliberals mobilised against contemporary hegemony: the social-democratic welfare state. ${ }^{43}$ They challenged the status quo and offered a new alternative vision and basis of argumentation centred on private and individual (rather than public and collective) ownership. Swedish neoliberalism took shape around the specific purpose to question the consensual norm in politics. As expressed in a neoliberal analysis of the failing bourgeoisie political project (in 1987):

The more [the bourgeoisie] disliked the class struggle - the more they advocated consensus. There is of course a limit where consensus is no longer possible. But psychological mechanisms easily work in a way that one who is inclined to confrontation compromise less than one who wants consensus. . . . They want so much consensus and wish to see as little political struggle that they gradually accept adaptation to an all the more politicised climate. They defend the proposals that they opposed yesterday as a desperate chance not to have to give in to further demands. ${ }^{44}$

Neoliberal intellectuals sought to challenge the social democratic hegemony and renegotiate what was 'politically impossible'. ${ }^{45}$ Through historical analyses of the 'privilege to define problems', ${ }^{46}$ they concluded that the labour movement had successfully defined the political agenda for the 20th century. 
Inspired by the Left, they developed strategies to redefine the social field as divided between two opposing camps: the individual (the underdog, the people, the 'common man', the oppressed masses, 'you', 'I', 'we', and so on) versus the welfare state (the establishment, power, social democracy, and so on). At the core of the neoliberal discourse that followed was not literally 'the people' but other inclusive forms of 'us' such as 'individuals' or 'human beings'. Paradoxically, the 'individual' which functioned as addressee, subject, and appeal was a collective, universal individual everyone could identify with. ${ }^{47}$ Neoliberalism represented the interest of 'ordinary people' while parliamentary parties (i.e. 'the establishment') represented the special interests of one class or another, it was argued. ${ }^{48}$ Much like the first wave of populism in Norway and Denmark, Swedish neoliberal populists protested against the strong taxation of the welfare state system. In Finland, there were only minor parties emerging with the (neo)liberal economic agenda with anti-Sovietism - for example, Liberal party, Georg C. Ehrnrooth's SPK/POP ${ }^{49}$ These have been largely marginalised and disappeared in contemporary Finnish politics. ${ }^{50}$

The Valco corruption scandal in 1979 gave a boost to the SMP who contested the rich elites and their abuse of power. A non-socialist government was not formed, but four years later, the party, hyperactive in their parliamentary activities, made it to the government in 1983 . They were brought into a coalition with the SDP and Centre Party - but they saw themselves in the middle of the two. ${ }^{51}$ It may have been better to keep them in parliament rather than active in opposition. Their support shrunk by 1987, but they joined the first post-war government led by the National Coalition and SDP. The 1980s were economically a boom in Finland with opening regulations and the "casino economy' (kasinotalous) overheating the market. The anti-elitist party being a junior partner in government led to criticism in terms of the metaphors of the softness of the seats of ministerial Audi's and accusations of party ministers having spines made of banknotes - the latter trope, seteliselkärankainen, actually signified a split in the party. In the 1980s, the bases for corporatisation of stateowned companies were laid..$^{52}$

The Norwegian Progress Party was redefined as a libertarian party in 1983 under the leadership of Carl I. Hagen. According to Swedish neoliberals, Hagen and his party did not measure up to mainstream media's descriptions of " "neoliberalism" or "populism". ${ }^{53}$ The party took aim at immigration in time for the 1987 local elections, when Hagen used a (now infamous) forged letter to portray a Muslim threat against Norwegian culture and Christianity. ${ }^{54}$ Still, Hagen argued as late as 1989 against 'insane' media accusations of xenophobia: 'Our profile has initially been, from the start in 1970, that we were against taxes, fees, and public intrusions. . . but we have long been in favour of an immigration stop, as long as we have a socialist welfare state' ${ }^{55}$ It was not until the 1990s that the party discourse would be rephrased around cultural differences and integration as key concerns. ${ }^{56}$ Meanwhile, neoliberal actors treated the Norwegian Progress Party as a fellow anti-welfare-state actor and downplayed their xenophobic tendencies. ${ }^{57}$ Just as the Finnish Rural Party was losing 
their connection with the people in the minds of many when they were in the government in the 1980s, similar criticism was directed at the Finns Party when in power in 2015-2017. The Sipilä government, analytically termed as a three-legged Aalto chair - well-integrated but wobbly - carried out antiwelfare state policies and tightened immigration policies. ${ }^{58}$

By 1989, Sweden was on the road to a fiscal, social, and political crisis that knocked the social democratic welfare-state project off its foundations. The minister of finance, social democrat Kjell-Olof Feldt, played a central role in the years and decisions leading up to the crisis. Feldt was generally recognised as a right-leaning economist. Swedish neoliberals applauded his inspirations from Thatcher and Reagan, welcomed him as 'the high priest of Neoliberalism' and described the following tax reforms as 'a form of Glasnost'. ${ }^{9}$ Neoliberal challengers to the social-democratic hegemony attempted to construct a chain of equivalences between the Swedish Social Democrats, the Soviet state, and politics in dissolution. In parallel to the Soviet Union, the Social Democrats attempted to save the system through reforms aimed at higher efficiency. Feldt, like the Soviet leaders, embarked on an extensive reform programme. Hence, the failing system and its rulers were constructed as the main offenders in the counter-hegemonic critique at the time. ${ }^{60}$

\section{0s: neoliberalism - from fringe to mainstream}

The Soviet Union's collapse and the end of the Cold War brought an end to the bipolar conflict. Neoliberal forces utilised this opportunity to administer economic shock therapy, and a wave of privatisation rolled across Northern and Eastern Europe. In several countries, neoliberal networks mobilised popular support, built coalitions, and framed privatisation as the only alternative to discredited statist systems. Social-democratic regimes (e.g. Poland, Sweden) launched economic reforms to transform and privatise state enterprises. Neoliberal emphases on private property and individualism shaped major aspects of these processes. ${ }^{61}$

Most analyses of Nordic populism focus exclusively on parliamentary party politics. ${ }^{62}$ From such a perspective it is easy to conclude that New Democracy were the only populists in Sweden and that they were largely unsuccessful especially when compared to the electoral success of Danish and Norwegian People's Parties. Yet, at the same time, neoliberal populists were able to move quickly from the margins to the mainstream, managing in the process to institutionalise political demands for decreased taxation and increased privatisation. They did so, however, without founding a parliamentary party. Instead they relied on extra-parliamentary ways of doing politics (think tanks, business associations, etc.). ${ }^{63}$ Their demands gained parliamentary support because they were taken up by conservative and social democratic MPs who felt compelled to partially align their views with the neoliberal movement. When analysts wonder at the seeming lack of populism in Sweden, they have simply been looking in the wrong place. Populism did indeed leave substantial marks on Swedish 
politics in the 1990s, but it did so largely through the extra-parliamentary politics of radical neoliberals who succeeded in their stated aim to make the 'politically impossible possible'. ${ }^{64}$

Sweden's first right-wing populist party, New Democracy, rolled in on a wave of populism created by the Swedish neoliberal movement. The party program was presented in 1990 in a context of severe fiscal and social crisis. While New Democracy mobilised against immigration policies from the outset, the xenophobic tendencies grew and became more apparent through the years. ${ }^{65}$ In 1991, the Swedish Social-Democratic party experienced their worst election since 1921; a right-wing government took office after nine years in opposition; and New Democracy, with their populist appeal, went from nonexistent to parliamentary success in less than a year (although their decline was nearly as swift). A shift in politics marked the end of the social democratic ideology that had permeated Swedish politics since 1932. The social democratic hegemonisation of politics and society had assured a political consensus on the Swedish democracy and welfare model, but, as neoliberal ideas permeated the public debate, this model was described as a problem rather than a solution. Affective appeals and emotional engagement abounded in neoliberal rhetoric. Mainstream public political debate was, however, characterised by rational reasoning and managerial concerns. Social Democrats defended the administrative systems. ${ }^{66}$ They argued in terms of efficiency, instead of formulating a politics for the masses against 'a few capitalists', as chairman of the Social Democrats and two-time prime minister Per Albin Hansson put it in the famous 'People's Home-Speech' (Folkhemstalet) of $1928 .{ }^{67}$

The Scandinavian populist parties all experienced crises in the mid-1990s. In 1993, conflicting factions were tearing the Norwegian Progress Party apart. So far, conservatives and radical neoliberals had been united by common interests in market economy and liberal alcohol policies. Opposition grew between an older generation of 'reactionaries' proposing 'large restrictions on immigration' and a younger generation of 'true liberals' in favour of 'completely free immigration, dismantling the welfare state', ${ }^{68}$ and so on, according to contemporary analysis by neoliberal intellectuals. Internal oppositions were even flaunted in televised debates in the aftermath of the poor election results of 1993. By 1997, immigration was framed as a threat to the existing socio-cultural harmony. With a rhetoric centred on ethnicity and difference, 'ethnic Norwegians' were coupled with norms and values like equality, peace and harmony, while immigration was linked to conflict and loss of equality. On top of re-gaining voter support from losses in 1993, the Progress Party became Norway's second-largest party in the 1997 national elections. ${ }^{69}$

In parallel, New Democracy's populist leader abruptly left the party after internal conflicts in 1994. With new leadership, the core signifiers of the party's discourse turned from taxes to immigration and electoral support plummeted. Like the Norwegian Progress Party and others that experience sudden success, New Democracy was unprepared for the number of seats they needed to fill. If the party had been better organised and less dependent on the two charismatic 
founders, it might have retained support. While the Progress Party in Norway was able to build alliances and reinvigorate their rhetoric, New Democracy failed at both. ${ }^{70}$

Likewise, internal conflicts and power struggles eventually spelled the end of the Danish Progress Party's success story. Kjærsgaard and her allies abandoned the party in the mid-1990s, and founded the Danish People's Party. In People's Party rhetoric, the ordinary people were positioned against the elite of wellto-do experts, intellectuals, and socialists. Much like the Swedish neoliberal discourse, the right-wing populist message of the Danish People's Party met little resistance from the Left. While the Danish People's Party shared many of the demands initially posed by the Danish Progress Party, the former promoted welfare chauvinism (for 'real' Danes) against public sector reductions and privatisations. The nationalist tendencies of the People's Party were clear, but they have nevertheless positioned themselves as equal to established right-wing parties. Simultaneously, right-wing nationalists attacked leftist values and ideals at all levels of society. ${ }^{71}$

If populist parties in the Scandinavian countries were able to challenge social democratic hegemonies through demands for increased privatisation and decreased taxes in the 1970s, 1980s and early 1990s, these notions became hegemonic themselves in the end. Therefore, we can speak of a hegemony that emerges and transforms over time. The central issues emerging from the 1970 s to the 1990 s are the relations to the Soviet Union and market deregulation. Populist parties have emerged as a response to dominant thinking in each of the political contexts. Yet these parties (and movements) take form around different points of contestation at different times, to contest cultures of consensus.

In Finland, the SMP spent the 1980s working inversely against unemployment and poverty, for example, through taxation. They were strongly antielitists, but having held power, their support was collapsing. In the early 1990s, the economic recession steepened due to collapsing Eastern trade with the collapse of the Soviet Union. SMP and its party newspaper consequently went bankrupt. ${ }^{72}$ In 1995, some of its key actors reinvented the party as the Finns Party (Perussuomalaiset). Simultaneously, in the ethnically relatively homogeneous Finland, the arrival of Somalian refugees and even the Ingrian people from the former Soviet Union neighbouring areas - the latter especially welcomed by Mauno Koivisto, whom the SMP supported for Finnish president - provoked some Finns Party politicians, notably Sulo Aittoniemi. ${ }^{73}$ For the Finns Party leader, Timo Soini (from 1997), the key point of contestation became the other parties and the European Union, which started to fill the hegemonic narratives in Finland in the 1990s. In complete contrast with the thinking of Veikko Vennamo, the original founder, the party adopted a stance against European integration and a critical perspective towards immigration and refugees. ${ }^{74}$ Welfare chauvinism became an entangled feature of the new party. ${ }^{75}$ This transformation could be attributed to the collapse of the Soviet other and Finlandisation of the Finnish self-image, and the need for new narratives. 
Other potential populist parties in Finland at this point included the Greens and the liberals, although the roots of the Green movement in Finland are longer. The emblematic populist environmental moment was the Koijärvi movement in 1979 that inspired a generation and boosted the organisation of a political party in the shape of a fringe populist force contesting all the existing parties to offer an alternative. ${ }^{76}$ The Greens have been strong in Helsinki for a long time as the third and then the second-largest party, but attained national relevance only in the late 2010s. This was partly due to the success of a veteran from the 1980s, Pekka Haavisto, and confrontational, even populist, rhetoric by their then leader Ville Niinistö. In 1973-1992, the small liberal party on the style of Scandinavian populists, Constitutional Right Party (Perustuslaillinen oikeistopuolue, POP), led by Georg C. Ehrnrooth originally of the Swedish People's Party, ${ }^{77}$ was right-wing particularly in terms of being anti-communist and against Kekkonen line. ${ }^{78}$ As SMP grew softer under Veikko Vennamo's son Pekka Vennamo's leadership, in particular, and joined governments, POP kept their 'fringe populism' going - until Ehrnrooth's point of contestation disappeared in the early 1990 s.

\section{0-2010s: mainstreaming fringe populism}

Euroscepticism has been relevant to some degree for all the Nordic populist parties. ${ }^{79}$ In the case of the Danish People's Party and Sweden Democrats, immigrants had been the source of identity after the hegemonic shift to the right in economic policies. This thinking also started to spread in Finland. One could also say that the Vennamo heritage on left-wing policies was lost and only the anti-elitist rhetoric (in the style of rötösherrat kuriin) remains in the renewed Finns Party programme. In the Nordic countries, populist parties moved more steadily from the fringe to the mainstream and other parties appropriated their ideas.

The 2000s saw the establishment of the Finns Party. In his master's thesis in 1988, the Finns Party chairman Timo Soini discussed Scandinavian populism. He also named Pia Kjærsgaard as his reference point in his opinion pieces in the Helsingin Sanomat in the 2000s. ${ }^{80}$ His rhetoric confirmed how the duality of anti-elitism and anti-EU overshadowed anti-immigration; yet the tension remained. In the early 2000s, the voice of the suburbs, Tony Halme, an iconic boxer, became an MP for the Finns Party in Helsinki. Meanwhile, Timo Soini was elected as one of the representatives of the Helsinki Region at the Finnish parliament. The real breakthrough came only after the 2007 general elections, and in particular in 2008, when the scandal of election funding and the Law of the Land (maantapa) was debated. Established political parties had developed practices through which they could avoid unveiling their sources of electoral funding. Set against the 'old parties', the Finns Party emerged as a novel alternative: it did well in the 2008 local elections, and it gained a landslide in the 2011 and 2015 elections. The voices of anti-immigration, with Jussi Halla-aho first elected to the Helsinki City Council in 2008, became intertwined with 
anti-elitism. However, as Arter argues, the party was for the so-called 'Finns' but not as aggressively as the Scandinavian counterparts. ${ }^{81}$

In Sweden, the Social Democratic Party turned right to navigate the crisis of the 1990s. The political playing field became increasingly crowded around the centre. All the more so when the conservative party incorporated former social democratic slogans into their rhetoric in the early 2000s. The four right-wing parties formed a common alliance in the mid-2000s, and the voters' political options were narrowed down to a choice between two 'blocs'. In addition, voters experienced that the difference between the established parties shrunk to such a degree that it hardly mattered which party you voted for. ${ }^{82}$ In this sedimented political culture, the Sweden Democrats gained attention as an alternative to the established order. The Sweden Democrats successfully exploited the political vacuum and presented themselves as the only viable political alternative to the disrupted consensus-oriented political elite. They adapted to the mainstream technical-rational political discourse by speaking of the costs of immigration, while mobilising voters with more affective appeals in their political propaganda. The organising principle of the Sweden Democrats' politics has always been the opposition between a national 'us' and the immigrant/non-Christian 'them' - unlike other Nordic populist parties, who initially focused on tax issues. In comparison with populist parties in Denmark, Norway, and Finland, the Sweden Democrats have lagged behind and only emerged as a real political contender since $2010-2014 .^{83}$

The three populist alternatives in Sweden (the New Democracy, the extraparliamentary neoliberals and the Sweden Democrats) share similar political strategies. Folklig is a term in Swedish (folkelig in Danish and Norwegian) that signifies practices that are popular, plebbish, or 'like ordinary people'. Politicians may strive to appear folkliga. When political spokespersons appear as ordinary people do - in sweatshirts and bucket hats in the case of New Democracy; with flaws or petty criminal behaviour (be it moonshining, tax evasion, gambling or drunk and disorderly behaviour) in the case of neoliberals or Sweden Democrats - their popularity increases. Both New Democracy and extra-parliamentary neoliberals emphasised fun, alcohol consumption, and common sense. New Democracy's campaign film from 1991 was even titled 'Common Sense'. ${ }^{84}$ They bragged about their vast number of volunteers but limited finances. They toured the country in boats and cars, and spoke on fun fairs, campsites, and squares. ${ }^{85}$ Stressing the need to 'listen to the people' on national television in 1990, party founder Bert Karlsson appeared as 'a man of the people' who sympathised with the less fortunate. In congruence with our point about the post-foundational understanding of populism, a populist party is not by definition representing the 'underclass' or represented by it. The co-founder and party leader Ian Wachtmeister stood in stark contrast with his upper-class roots and ideological message of radical market liberalism coupled with anti-immigration. It has since been 'the count' Wachtmeister, rather than 'the valet' Karlsson, who the Sweden Democrats have consulted in their election campaigns. ${ }^{86}$ 
New Democracy used rhetorical tropes that had been prominent among neoliberal radical intellectuals for many years: to take from the state and give to the individual, and so on. Their rhetoric positioned common people against politicians and their 'contempt for people'. In short, they contested the political status quo through affective arguments that appeal to the audience's sense of neglect. New Democracy's populist logic built on an 'us' that integrated disparate identities under a common identity: 'the common people'. It identified established politicians as 'them'. In the preceding, broader neoliberal discourse, the populist logic is even clearer. There, the unifying 'us' mobilised against the system was the people as individuals, and the political 'frontier' was set against the social-democratic welfare state. ${ }^{87}$

As long as Sweden was characterised by a social-democratic hegemony, populism was voiced as an opposition to the social-democratic welfare state. Lately, the Sweden Democrats have begun to frame their politics as a more traditional version of social democracy - in contrast to the contemporary Social-Democratic Party. Since the social-democratic welfare state has lost its hegemonic standing in Swedish politics, it no longer functions as the main opponent of populist politics. Consequently, these actors are left grappling for a new frontier. In positioning themselves as the true Social Democrats, spokespersons for the Sweden Democrats have made use of the old concept Folkhemmet (the people's home). ${ }^{88}$ Folkhemmet is a 'shining example' ${ }^{89}$ of the culture of consensus mentioned at the beginning of this chapter and was produced by a historic compromise between capital and labour. However, it was also an important metaphor for the successful social democratic hegemonisation of Swedish political discourse, as argued by Erik Åsard and W. Lance Bennett. ${ }^{90}$ It has long since been obsolete in social democratic rhetoric.

The folkhem metaphor has now been re-activated by the Sweden Democrats to appeal to traditional social democratic voters - all the while articulating a nostalgic vision for the Swedish nation. The Social Democratic Party represents the political elite, just as it did in the neoliberal populist discourse of the 1980s and 1990s. ${ }^{91}$ The argument is that the Social Democratic Party has betrayed their ideological roots as well as the Swedish people. ${ }^{92}$ The Sweden Democrats' financial politics have turned increasingly towards a market liberal agenda during the past decade. Paradoxically, the party's attitude to trade unions and workers' rights have simultaneously taken a turn to the left, as voter support among unionised blue-collar workers increasingly favour the Sweden Democrats. ${ }^{93}$

Remembering the emptiness at the core of populism, we should also consider left populism. Recently, leftist aspirations in Sweden challenge the neoliberal hegemony through conscious and explicit populist politics inspired by Chantal Mouffe's advocacy for a left populism. ${ }^{94}$ That is, a logic of articulation that places the universal identification 'us' in a dichotomy with 'them'. Moving on from an attempt to re-assert class as the central signifier in political discourse, ${ }^{95}$ social democratic think tank intellectuals recently initiated a new group within the Swedish Social Democratic Party: 'the Reformists' (Reformisterna). These Reformists 
challenge the neoliberal hegemony in and outside the Social Democratic Party. With demands to 'reinstate the monetary system', they attempt to construct a political frontier between 'ordinary people' and 'the economic elite'. ${ }^{96}$ Through the articulation of a reform program that highlights a Green New Deal, they link together multiple environmental and economic struggles around a demand for equality and social justice against the status quo. ${ }^{97}$ Using the 'ordinary people' as a point of identification enables them to reclaim voters from the Sweden Democrats - without constructing the latter or their voters as the enemy.

The Reformists actively challenge the status quo in both politics and media. Swedish news media have adopted a cultural valuation scale (GAL-TAN) from the political sciences in attempts to explain the successes of what they call populism: the Sweden Democrats, Brexit, Trump, the Finns Party, and so on. According to mainstream media, 'the old battle between right and left' ${ }^{\text {' }}$ has been replaced by one between liberal globalists and conservative nationalists. In contention, the Reformists expose hegemonic practices that cover up redistributive concerns. That is to say, they have emerged as a response to dominant thinking in Swedish politics and contest the status quo where cultural concerns are said to have replaced economic concerns.

The Finns party had a landslide in 2011 but remained in opposition. In Finland, the Finns Party went to a neoliberal austerity government in 2015 with the Centre Party and the National Coalition. The millionaire faction in power in the Centre moved quite far from some of their traditional values, and after the failure in 2019 and steep decline in the party membership, the party changed leadership. The Finns Party term in office led to the decline of its support. Some also argued that the government did not succeed in containing immigration. The leadership was challenged and changed by a faction that mobilised on social media and Hommafoorumi online platform in the party congress in June 2017. The congress elected Jussi Halla-aho, an MEP known for his strong anti-immigration and civilisationist stance and founder of the platform, as party leader. None of the five ministers or those close to the founding member and chairman of the FP were chosen in the leadership. This faction, comprising half of the parliamentary caucus, stepped out and by autumn 2017 established a new party: Blue Reform (Sininen tulevaisuus).

With the transformed leadership, the Finns Party succeeded in the 2019 elections becoming one of the three largest parties. After the elections, fierce debates over whether or not they should be sitting at the right-wing end of the parliament where they were now assigned, as their economic policy resembled the early versions of Nordic right-populist parties. The earlier seat in the centre originated from the SMP, a splinter from the Agrarian Party, and an economic policy between the Left and the Right - until Juha Sipilä's austerity government (2015-2017) and leadership change. The Blue Reform were, however, not successful in the polls in the 2019 elections and did not run in the elections to the European Parliament, and Finns Party, while becoming the main opposition party and the most popular party in the polls in the summer 2019, did not do as well in the Euroelections as those for Eduskunta. 
The week preceding the European parliament elections of 2019 were overshadowed by the question of Russian influence in the newly forming nationalist bloc that included cooperation between Italian Lega, Freedom Party of Austria, and others with Nordic populist parties. The issue of hegemonic struggle with the eastern neighbour re-surfaced. It became apparent that several European populist parties, such as Matteo Salvini's Lega in Italy or the Austrian FPÖ, with video-exposed leader Heinz-Christian Strache, had close ties to Vladimir Putin's Russia. Considering the anti-Soviet heritage, this could have contributed to their poor result in comparison to the polls in general. As the traditional national identity in Finland is formed through what it is not (Russian or Swedish), questions remain to what extent the Finnishness in the renewed Finns Party is defined through opposition to Russia or the European Union or simply the migrants. The Sweden Democrats did not join this coalition.

In Norway and Denmark, the Progress Party and People's Party respectively managed to secure increased voter support through the 2000 s despite a series of scandals. ${ }^{99}$ Both have survived changes in leadership, replacing long-term leaders Hagen and Kjærsgaard, respectively. Widespread scepticism among the other Norwegian parliamentary parties initially made it difficult for the Progress Party to practice its theoretical leverage. The Danish People's Party and the Sweden Democrats alike have transformed themselves by adapting social democratic ideals and rhetoric. Simultaneously, more radically right-wing and anti-immigrant or anti-Muslim parties emerge to challenge already-established populist parties from even stronger fringe positions. In the 2019 parliamentary elections, the Danish People's Party suffered a significant setback - halving their voter support - which can, if only in part, be attributed to the rise of new fringe parties. This is largely due to the Social Democrats adapting their lost rhetoric and combining it with a tough-on-immigration stance that had now become mainstream.

Addressing the overall transformations and political logics in different contexts, it is easy to see that the contents of demands and policies vary much more than the forms of their presentation do. Like the neoliberal movement, early right-wing populist parties in Norway and Denmark were neither ethnonationalist nor mobilised against immigration (until the 1980s). The Sweden Democrats have, on the contrary, always been ethno-nationalist and antiimmigration but never neoliberal: they vote with the Social Democrats and Left party in many instances concerning labour market policies and workers' rights. One thing is clear, however: the fringe populist parties mainstreamed themselves in the 2000s. However, many of them either fell back to a fringe position, such as in Finland, or were pushed there by more popular parties, as in the Danish case.

\section{Transforming hegemony}

There are several conjunctures that we can draw on that also have to do with international politics and are transnational. Going back to the 1960s, the 
Finnish populist SMP was born out of the direct reaction against the Sovietfriendly politics epitomised in the figure of Urho Kekkonen as the head of the Agrarian party, and finally the longest-serving president. The coupling of the Soviet developments and the domestic politics in the Nordic countries continued in terms of populist parties. As the Washington Consensus was establishing and the Soviet model crumbling, the populist parties also sought to question either the foreign policy related to it (in Finland) or the economic models that gained their raison d'être from the response to those models (Sweden and Scandinavia). In both Sweden and Finland, market deregulation discussions started in the 1980s. In the geographically more western Scandinavian countries Norway and Denmark, populist parties had already contested the idea of high taxation as a basis of the welfare-state model. As market liberalism was declared the winner in the Cold War global ideological contest, Soviet-style economies crumbled, welfare states were transformed, and communism no longer provided a political Other, the populist parties and movements were losing their point of contestation. In the 1990s, while the Finnish economy was in recession, in Sweden some claimed that the Soviet economy was privatising 'too fast'; others believed that it was not fast enough; but all agreed that privatisations were necessary. ${ }^{100}$

The intertwining of neoliberalism and anti-immigration discourses often goes unexplained as a curiosity in Nordic populism research. The rationalising argument that supported neoliberal reforms, stressed as a given that the welfare state is not affordable. This led to nationalism coupling with the welfare chauvinism that tries to rescue what is left of the welfare state and safeguard it from the newcomers. The recent turn of the Danish People's Party to early social democratic ideals and the Sweden Democrats' emphasis on the nostalgia of Folkhemmet that includes the welfare state testify to this process. Going back to the theoretical framework and our formula Populism $=u s^{\text {affect } 1}+$ frontierffect 2 , we ask ourselves what picture of populism is emerging? Clearly each period has its own contents, but overall we argue that in the Scandinavian countries, the frontier feature to be opposed became welfare statism, to which individualism and market economy were contrasted; while in Finland, the confrontation thrived with anti-Sovietism:

Scandinavian Populism $(1970-2000)=$ people-as-individuals anti-system $^{-}$welfare statism $^{\text {past-system }}$

Finnish Populism $(1970-2000)=$ ordinary people $e^{\text {inclusion }}+$ Soviet-lead loss of independence $^{\text {. }}$

Affects are a dimension we have not closely studied here - we add here antisystem confrontation and the naming of something as past and allusion of independence as potentials. The rhetoric of neoliberalism was affective in that it provided a vision of a new era and recognised of the individuals rather than a system (with clear anti-Soviet tones). In the Finnish case, one could hypothesise that populism provided healing for the loss. Moving to the 2000s, it was replaced by nationalism that highlighted the Nordic people versus immigrants 
axis. However, even here, it is about livelihoods: transforming neighbourhoods or surroundings as well as the foreign element of religion heightened the frontier concept. ${ }^{101}$ However, welfare returns to the side of the 'us', as an affective dimension where welfare could also feature alongside nationalism. One interpretation could look like this:

\section{Nordic Populism $(2000-2010 s)=$ Nordic people $e^{\text {welfare-nationalism }}+$ immigrants transforming-communties}

We argue that welfare chauvinism restores the belief in the welfare state. In the Scandinavian countries, populists, and in Finland, some other parties spoke for years against the welfare state as a luxury to be afforded on a global scale, which has paved the way for welfare chauvinism. Fear of losing the welfare state in the face of the newcomers could explain a particular transformation that took place. In a sense, this fear was used by neoliberals in the 1980 s - but their solution was to cut welfare expenditure and support for all, not just for a few. In short, the argument on the need to cut welfare provision in terms of economic efficiency and ageing populations provokes responses that are welfare chauvinism. This is how neoliberalism and anti-immigration can get entangled in populist meaning-making. ${ }^{102}$

We conclude that, using the framework of the formula of populism, it is easy to see that the political Other has transformed: the frontier used to mark a contrast to the welfare-statist regulated market, or the collaboration with the USSR in Finland, but as marked deregulation mainstreamed, the contestation focused on the suspicion of newcomers, sometimes with welfare-chauvinist undertones. The political 'us' emerged from this contestation as a relatively monoethnic constellation.

\section{Notes}

1 Laclau 2005.

2 Hawkins, Carlin, Littvay \& Kaltwasser 2018, Jungar \& Jupskås 2014.

3 Laclau 2005, Laclau \& Mouffe 1985, Mouffe 2018, Palonen 2021.

4 Arter 2010.

5 Arter 2013, Elder, Thomas \& Arter 1988.

6 Östberg 2018. See also Kjell Östberg's chapter in this volume.

7 E.g. Arter 2013, Hagelund 2005, Wingborg 2016.

8 E.g. Rydgren 2006.

9 Ylä-Anttila 2017, Hatakka 2019.

10 Palonen 2018, Palonen \& Saresma 2017.

11 Cf. Freeden 2017.

12 Laclau 2005, 2014, Laclau \& Mouffe 1985, Mouffe 2018.

13 See also Palonen 2020.

14 Palonen 2018, 2020.

15 Laclau develops on Claude Lefort's democratic theory in Laclau 2005. See also Lefort 1988 and Näsström 2007.

16 Götz \& Marklund 2014.

17 Polarisation may mean a bipolar hegemony, where two camps would be apparently consensual and single-voiced, each camp co-constituting the other (Palonen 2009). 
18 Mouffe 2000.

19 Jungar 2015.

20 Møller Hansen \& Stubager 2017.

21 Elmgren 2014. See also Rainio-Niemi 2014 in the same volume.

22 Andersen \& Bjørklund 1990, Jens Rydgren 2010.

23 Rydgren \& van der Meiden 2018, Taggart 1996. Historically, Swedish right-wing parties had to form majority coalitions to take government office. The Social Democrats used to be able to form minority governments, but their voter support has dwindled in the past decades. The left-right divide between parties willing to cooperate has long been clear but was sharpened in the 2006 election. In the mid-2000s, the four right-wing parties agreed to run for office together in an 'alliance for Sweden'. Since, only two government alternatives have been represented in Swedish politics, despite the existence of various parties in a party-list proportional system.

24 Rainio-Niemi 2014.

25 Virtanen 2018, Aalto 2018.

26 See also Roikonen, Eloranta \& Ojala in this volume.

27 Rydgren \& van der Meiden 2018.

28 Fryklund 2018, Rydgren 2006.

29 Sunnercrantz 2017.

30 Virtanen 2018.

31 Ibid., 170-171

32 Sänkiaho 1971.

33 Virtanen 2018, 265.

34 Ibid.

35 Ibid., Arter 2010.

36 Ethnic homogeneity has been significant in Finland, where other ethnic groups have been small. Migration policy, apart from settling the Eastern Karelian population, and especially strategy hardly existed as Tilli (2019) explains. With the arrival of immigrants in Finland from Somalia, racism emerged in the 1990s as an explicit political issue. This is not to say there had not been racism before in Finland or the Nordic countries. Rather, particularly against the Sami minority in Sapmi (which stretches across Norway, Sweden, and Finland) and Inuits in Greenland, this had been carried out even at the level of policy. Other historical minorities such as the Roma and Tatars in Finland were not exempted from (institutionalised) racism.

37 Aarhus University 2019, Jens Rydgren 2010, Stubager et al. 2016, Taggart 1996, Ydling Brunbech 2011.

38 Kvanmo \& Rygnestad 1993.

39 E.g. Nevalainen 2018.

40 Jens Rydgren 2010, Ydling Brunbech 2011.

41 Karpantschof 2006.

42 Hort 2014. See also Östberg's chapter in this volume for further discussion on the employee funds.

43 Sunnercrantz 2017.

44 Westholm 1988, 39.

45 Segerstedt 1988.

46 Westholm 1988, 26.

47 Sunnercrantz 2020.

48 See e.g. Borg 1992, Norberg 1993a, Westholm 1988.

49 Keski-Rauska 2015.

50 Yet this legacy somehow prevails with the celebrity politician and parliamentarian Harry Harkimo of Movement Now (Liike NYt) - formerly of the National Coalition (Kokoomus), who has been establishing his movement in the model of the Five Star Movement in Italy.

51 Virtanen 2018. 
52 Nevalainen 2018.

53 Du Reitz 1989, 14; cf. Schoolland 1993.

54 Hagelund 2005.

55 Du Reitz 1989, 14.

56 Hagelund 2005.

57 See Wingborg 2016, cf. Du Reitz 1989, Schoolland 1993.

58 Palonen 2017.

59 Varveus 1989.

60 See e.g. Ibid.: 'rid the system of the worst perversions'.

61 Bohle \& Neunhöffer 2006, Sunnercrantz 2017.

62 Cf. Betz 1994, Fryklund 2018, Rydgren 2006, Taggart 1996.

63 Cf. Fryklund 2018, Jens Rydgren 2010, Taggart 1996.

64 Segerstedt 1988.

65 Taggart 1996, Widfeldt 2015.

66 Sunnercrantz 2017.

67 Hansson 1928.

68 Norberg 1993b, 7. Furthermore, the author argues:

If the conservatives were to win the struggle, the party would become more traditionally social-democratic combined with xenophobia and moralism. One can at least be glad that a conservative Progress Party would slowly but surely wither, without the youthful regeneration and intellectual capacity that only the young neoliberals have.

69 Hagelund 2005.

70 Taggart 1996, Widfeldt 2015.

71 Karpantschof 2006, Stubager et al. 2016, Taggart 1996, Ydling Brunbech 2011.

72 Virtanen 2018.

73 Prindiville \& Hjelm 2018.

74 Virtanen 2018.

75 Keskinen 2016, Kuisma 2013.

76 Aalto 2018.

77 Despite the name, the Swedish People's Party defended the Swedish minority in Finland, and while they may have populist undertones at times, they were an ethnic minority party.

78 Keski-Rauska 2015.

79 Herkman 2017, Raunio 2007.

80 Palonen 2017.

81 Arter 2010.

82 Hellström \& Nilsson 2010.

83 Widfeldt 2015. Inspired by the Danish populist right, the Sweden Democrats toned down their nationalistic elements. Despite established parties' and mass media's conviction that parties like the Danish Progress Party and the Sweden Democrats would never become 'potty trained' both parties have strived to disprove them. See Dahlerup 2008, Lindberg 2011, Wingborg 2016.

84 Cederquist 1991.

85 Ibid., Dahlbäck 2013.

86 Dahlbäck 2013, Widfeldt 2015, Wingborg 2016.

87 Sunnercrantz 2017.

88 With reference both to Per-Albin Hansson and the more nationalist politician and political scientist Rudolf Kjellén. See Hellström 2010.

89 Arter 2013, 152.

90 Åsard \& Bennett 1997.

91 Sunnercrantz 2020.

92 Hellström 2010, Hellström \& Nilsson 2010, see also 'Torehammars supervalår', 140813. 
93 Hellström \& Lodenius 2016, Sundell 2015, Wingborg 2016.

94 See e.g. Greider \& Linderborg 2018, Suhonen \& Gerin 2018.

95 Katalys, Klass i Sverige.

96 Socialdemokratiska föreningen Reformisterna.

97 Ibid.

98 ' $[\mathrm{A}]$ prerequisite for both the traditional block policy and the alliance building', according to Marmorstein 2019.

99 Herkman 2018.

100 See Sunnercrantz 2017.

101 In the case of Denmark, the frontier has partly ceased to be external to the country. Instead, it has been reconstructed and manifested internally through the state's designation of 'ghettos' and the more recent policy programme against 'parallel communities'.

102 Palonen 2018.

\section{References}

Aalto, Sari, 2018: Vaihtoehtopuolue: Vihreän liikkeen tie puolueeksi. Helsinki: Into Kustannus. Aarhus University, 2019. The Danish Election Database. https://valgdatabase.dst.dk/ [Accessed 8 October 2019].

Andersen, Jørgen Goul \& Bjørklund, Tor, 1990: "Structural Changes and New Cleavages: The Progress Parties in Denmark and Norway" in Acta Sociologica, 33:3, 195-217.

Arter, David, 2010: "The Breakthrough of Another West European Populist Radical Right Party? The Case of the True Finns" in Government and Opposition, 45:4, 484-504.

Arter, David, 2013: Scandinavian Politics Today. 2nd ed. Manchester: Manchester University Press.

Åsard, Erik \& Bennett, W. Lance, 1997: Democracy and the Marketplace of Ideas: Communication and Government in Sweden and the United States. Cambridge: Cambridge University Press.

Betz, Hans-Georg, 1994: Radical Right-Wing Populism in Western Europe. London: Palgrave Macmillan.

Bohle, Dorothee \& Neunhöffer, Gisela, 2006: "Why is there no Third Way? The Role of Neoliberal Ideology, Network and Think Tanks in Combating Market, Socialism and Shaping Transformation in Poland" in Dieter Plehwe, Bernhard Walpen \& Gisela Neunhöffer (eds.) Neoliberal Hegemony: A Global Critique. London and New York: Routledge.

Borg, Anders E., 1992: Generell välfärdspolitik - bara magiska ord? Stockholm: City University Press.

Cederquist, Peter, 1991: Ny Demokratis valfilm 'Sunt förnuft'. www.youtube.com/watch?v= KAlghcy6_TU [Accessed 27 September 2019].

Dahlbäck, Vincent, 2013: "Händelser som skakat Sverige: Ny Demokrati” pt. 4:8, 'Svenska händelser - De ville förändra svensk politik radikalt' in SVT 2, 2 April 2013. www.svt.se/ svenska-handelser/de-ville-forandra-svensk-politik-radikalt.

Dahlerup, Drude, 2008: "En politisk tragedi" in Aftonbladet, 29 June 2008. www.afton bladet.se/a/ng9rEQ [Accessed 11 March 2019].

Du Reitz, Einar, 1989: "Carl I Hagen - Libertarian eller opportunist?" in Nyliberalen, 1989:3, 14-15, 17.

Elder, Neil Thomas Alastar H. \& Arter, David, 1988: The Consensual Democracies? The Government and Politics of the Scandinavian States. Oxford: Basil Blackwell.

Elmgren, Ainur, 2014: “The Nordic Ideal: Openness and Populism According to the Finns Party" in Norbert Götz \& Carl Marklund (eds.) The Paradox of Openness: Transparency and Participation in Nordic Cultures of Consensus. Leiden: Brill, 91-119. 
Freeden, Michael, 2017: “After the Brexit Referendum: Revisiting Populism as an Ideology" in Journal of Political Ideologies, 22:1, 1-11.

Fryklund, Björn, 2018: "Populism in the Nordic Countries 1965-2015: The Swedish Case as an Ideal Type or Comparative Yardstick for the Development of Populism" in Urpo Kovala, Emilia Palonen, Maria Ruotsalainen \& Tuija Saresma (eds.) Populism on the Loose. Jyväskylä: Jyväskylän yliopisto.

Götz, Norbert \& Marklund, Carl (eds.) 2014: The Paradox of Openness: Transparency and Participation in Nordic Cultures of Consensus. Leiden: Brill.

Greider, Göran \& Linderborg, Åsa, 2018: Populistiska manifestet: för knegare, arbetslösa, tandlösa och 90 procent av alla andra. Stockholm: Natur \& Kultur.

Hagelund, Anniken, 2005: "The Progress Party and the Problem of Culture: Immigration Politics and Right Wing Populism in Norway" in Jens Rydgren (ed.) Movements of Exclusion: Radical Right-Wing Populism in the Western World. New York: Nova Science.

Hansson, Per Albin, 1928: Folkhemmet, medborgarhemmet. Speech in Second Chamber Parliament, 18 January 1928. www.peralbinhuset.se/folkhemstalet.html [Accessed 5 December 2018].

Hatakka, Niko, 2019: Populism in the Hybrid Media System. Turku: University of Turku.

Hawkins, Kirk A., Carlin, Ryan E., Littvay, Levente \& Kaltwasser, Cristóbal Rovira, 2018: The Ideational Approach to Populism: Concept, Theory, and Analysis. London: Routledge.

Hellström, Anders, 2010: "Det nya folkhemspartiet" in Fronesis, 34, 110-124.

Hellström, Anders \& Lodenius, Anna-Lena, 2016: Invandring, mediebilder och radikala högerpopulistiska partier $i$ Norden. Stockholm: Delegationen för migrationsstudier.

Hellström, Anders \& Nilsson, Tom, 2010: “'We are the Good Guys': Ideological Positioning of the Nationalist Party Sverigedemokraterna in Contemporary Swedish Politics" in Ethnicities, 10:1, 55-76.

Herkman, Juha, 2017: "Articulations of Populism: The Nordic Case" in Cultural Studies, $31: 4,470-488$.

Herkman, Juha, 2018: "Old Patterns on New Clothes? Populism and Political Scandals in the Nordic Countries" in Acta Sociologica, 61:4, 341-355.

Hort, Sven E. O., 2014: Social Policy, Welfare State, and Civil Society in Sweden. Vol. 1, History, Policies, and Institutions 1884-1988. Lund: Arkiv.

Jungar, Ann-Cathrine, 2015: "Agrarian Populism in Finland: Continuity and Change" in Dirk Strijker, Gerrit Voerman \& Ida Terluin (eds.) Rural Protest Groups and Populist Political Parties. Wageningen, NL: Wageningen Academic Publishers.

Jungar, Ann-Cathrine \& Jupskås, Anders Ravik, 2014: "Populist Radical Right Parties in the Nordic Region: A New and Distinct Party Family?" in Scandinavian Political Studies, 37:3, 215-238.

Karpantschof, René, 2006: "Højreradikalismen i Danmark - en politik model på historisksociologisk grund" in Dansk Sociologi, 14:3, 25.

Katalys, Klass i Sverige: Om Katalys stora klassutredning: Klass i Sverige - Katalys. www.katalys. org/klass/ [Accessed 13 February 2019].

Keskinen, Suvi, 2016: "From Welfare Nationalism to Welfare Chauvinism: Economic Rhetoric, the Welfare State and Changing Asylum Policies in Finland" in Critical Social Policy, 36:3, 352-370.

Keski-Rauska, Riku, 2015: Yksinäinen Ehrnrooth. Georg C. Ehrnrooth YYA-Suomen puristuksessa. Helsinki: Otava.

Kuisma, Mikko, 2013: "'Good' and 'Bad' Immigrants: The Economic Nationalism of the True Finns' Immigration Discourse" in Umut Korkut et al. (eds.) The Discourses and Politics of Migration in Europe. New York: Palgrave Macmillan, 93-108. 
Kvanmo, Hanna \& Rygnestad, Arild, 1993: Anders Langes saga. Oslo: Norske samlaget.

Laclau, Ernesto, 2005: On Populist Reason. London: Verso.

Laclau, Ernesto, 2014: The Rhetorical Foundations of Society. London: Verso.

Laclau, Ernesto \& Mouffe, Chantal, 1985: Hegemony and Socialist Strategy: Towards a Radical Democratic Politics. London: Verso.

Lefort, Claude, 1988: Democracy and Political Theory. Cambridge: Polity Press.

Lindberg, Anders, 2011: "SD är inte rumsrena" in Aftonbladet, 11 July 2011. www.afton bladet.se/a/0EL73G [Accessed 11 March 2019].

Marmorstein, Elisabeth, 2019: "Utdragen maktkamp med given utgång" in SVT Nyheter, 3 March. www.svt.se/nyheter/inrikes/utdragen-maktkamp-med-given-utgang [Accessed 13 February 2019].

Møller Hansen, Kasper \& Stubager, Rune, 2017: Opror fra udkanten: folketingsvalget 2015. København: Jurist- og Økonomforbundet.

Mouffe, Chantal, 2000: The Democratic Paradox. London: Verso.

Mouffe, Chantal, 2018: For a Left Populism. London: Verso.

Näsström, Sofia, 2007: "The Legitimacy of the People" in Political Theory, 35:5, 624-658.

Nevalainen, Pasi, 2018: "Deadlock in Corporate Governance: Finding a Common Strategy for Private Telephone Companies, 1978-1998" in Business History, 60:6, 908-929.

Norberg, Johan, 1993a: "Välfärdspolitikens teoretiska grunder vacklar" in Nyliberalen, 1993:4, 66-67.

Norberg, Johan, 1993b: "Sönderfallande Fremskrittsparti” in Nyliberalen, 1993:7, 7.

Östberg, Kjell, 2018: "När ingen längre kokar kaffe - eller vad har hänt folkrörelsepartierna?" in Henrik Meinander, Petri Karonen \& Kjell Östberg (eds.) Demokratins drivkrafter: kontext och särdrag i Sveriges och Finlands demokratier 1890-2020. Stockholm: Appell förlag.

Palonen, Emilia, 2009: "Political Polarisation and Populism in Contemporary Hungary" in Parliamentary Affairs, 62:2, 318-334.

Palonen, Emilia, 2017: "Finland" in European Journal of Political Research: Political Data Yearbook, 92-98.

Palonen, Emilia, 2018: "Performing the Nation: The Janus-Faced Populist Foundations of Illiberalism in Hungary" in Journal of Contemporary European Studies, 26:3, 308-321.

Palonen, Emilia, 2020: “Ten Theses on Populism” in Emmy Eklundh \& Andy Knott (eds.) The Populist Manifesto. London: Rowman \& Littlefield, 55-69.

Palonen, Emilia, 2021: "Democracy vs. Demography: Rethinking Politics and the People as Debate" in Thesis Eleven. https://doi.org/10.1177/0725513620983686

Palonen, Emilia \& Saresma, Tuija (eds.) 2017: Jätkät E jytkyt: Perussuomalaiset ja populismin retoriikka. Tampee: Vastapaino.

Prindiville, Nicholas \& Hjelm, Titus, 2018: “The 'Secularization' and Ethnicization of Migration Discourse: The Ingrian Finnish Right to Return in Finnish Politics" in Ethnic and Racial Studies, 41:9, 1574-1593.

Rainio-Niemi, Johanna, 2014: “A Nordic Paradox of Openness and Consensus? The Case of Finland" in Norbert Götz \& Carl Marklund (eds.) The Paradox of Openness: Transparency and Participation in Nordic Cultures of Consensus. Leiden: Brill, 27-49.

Raunio, Tapio, 2007: "Softening but Persistent: Euroscepticism in the Nordic EU Countries" in Acta Politica, 42:2-3, 191-210.

Rydgren, Jens, 2006: From Tax Populism to Ethnic Nationalism: Radical Right-Wing Populism in Sweden. New York: Berghahn Books.

Rydgren, Jens, 2010: "Radical Right-Wing Populism in Denmark and Sweden: Explaining Party System Change and Stability” in SAIS Review, 30:1, 57-71. 
Rydgren, Jens \& van der Meiden, Sara, 2018: “The Radical Right and the End of Swedish Exceptionalism" in European Political Science, 18:3, 439-455.

Sänkiaho, Risto, 1971: "A Model of the Rise of Populism and Support for the Finnish Rural Party" in Scandinavian Political Studies, 6:1, 27-47.

Schoolland, Ken, 1993: "A Libertarian Odyssey" in Freedom Network News. http://rkba.org/ libertarian/isil/fnn/fnn02.txt [Accessed 11 March 2019].

Segerstedt, Torgny T., 1988: Det politiskt omöjliga. Stockholm: Ratio.

Socialdemokratiska föreningen Reformisterna, 2019. Reformprogram Reformisterna. www. reformisterna.se/reformprogram [Accessed 26 September 2019].

Stubager, Rune, Møller Hansen, Kasper, Callesen, Kristoffer, Leed, Andreas \& Enevoldsen, Christine, 2016: Danske volgere 1971-2015: en oversigt over udviklingen i volgernes holdninger $m v$. Aarhus: Det danske valgprojekt, Aarhus University.

Suhonen, Daniel \& Gerin, Enna, 2018: "Socialdemokraterna måste lära av vänsterpopulisterna" in Dagens Nyheter, 18 November 2018. www.dn.se/debatt/socialdemokraternamaste-lara-av-vansterpopulisterna/ [Accessed 15 January 2019].

Sundell, Anders, 2015: "Sverigedemokraterna röstar oftare med Socialdemokraterna än med Moderaterna” in Politologerna, 22 May 2015. https://politologerna.wordpress. com/2015/05/22/sverigedemokraterna-rostar-oftare-med-socialdemokraterna-an-medmoderaterna/ [Accessed 10 March 2019].

Sunnercrantz, Liv, 2017: Hegemony and the Intellectual Function: Medialised Public Discourse on Privatisation in Sweden 1988-1993. PhD dissertation. Lund: Lund University.

Sunnercrantz, Liv, 2020: "Vom Gegner lernen. Der anti-etatistische und nicht-nationalistische Populismus der neoliberalen Rechten in Schweden" in Seongcheol Kim \& Aristotelis Agridopoulos (eds.) Populismus, Diskurs, Staat. Baden-Baden: Nomos.

Taggart, Paul A., 1996: New Populism and the New Politics: New Protest Parties in Sweden in a Comparative Perspective. Basingstoke: Palgrave Macmillan.

Tilli, Jouni, 2019: "Finnish Discourses on Immigration, 2015-2016: Descendants of Ishmael, Welfare Surfers, and Economic Assets" in Jouni Tilli \& Clarke Rountree (eds.) National Rhetorics in the Syrian Immigration Crisis: Victims, Frauds, and Floods. East Lansing: Michigan State University Press.

Torehammars supervalår, 'Utfrågning och livequiz med Jimmie Åkesson (SD)', 140813.

Varveus, Anders, 1989: “Glasnost på finansdepartementet?” in Nyliberalen, 1989:1, 3.

Virtanen, Aarni, 2018: Vennamo: mies ja hänen puolueensa. Helsinki: Art House.

Westholm, Carl-Johan, 1988: "Borgerligheten som kyrkoruin" in Torgny T. Segerstedt (ed.) Det politiskt omöjliga. Stockholm: Ratio.

Widfeldt, Anders, 2015: Extreme Right Parties in Scandinavia. London: Routledge.

Wingborg, Mats, 2016: Den blåbruna röran: SD:s flirt med Alliansen och högerns vägval. Stockholm: Leopard förlag.

Ydling Brunbech, Peter, 2011: "Fremskridtspartiet 1972-2001" in danmarkshistorien.dk. https://danmarkshistorien.dk/leksikon-og-kilder/vis/materiale/fremskridtspartiet/ [Accessed 10 February 2019].

Ylä-Anttila, Tuukka, 2017: The Populist Toolkit: Finnish Populism in Action 2007-2016. Helsinki: University of Helsinki. 